\title{
The role of patron dining experience and emotions on relationship quality in chain restaurant industry
}

\author{
Ying Tuan Lo(iD, Siti Rahmah Awang(iD), Ahmad Jusoh(iD, \\ Khalil Md Nor(D), Khairiah Soehod (iD) \\ Faculty of Management, Universiti Teknologi Malaysia (Malaysia) \\ lyingtuan@botmail.com,sitirahmah@utm.my,abmadj@utm.my,m-khali@utm.my,kbairiah@management.utm.my
}

Received July, 2017

Accepted March, 2018

\section{Abstract}

Purpose: This paper investigates the role of patron dining experience (PDE) and emotions on relationship quality in the chain restaurant industry.

Design/methodology: Stratified random sampling method was used where questionnaires were distributed to the respondents in 16 selected 'Kopitiam' outlets throughout Malaysia. The empirical findings from 316 customers of those outlets were examined using Partial Least Squares (PLS).

Findings: The findings provide strong evidence of the relationships between PDE and emotions with relationship quality, where relationship quality in turn is an essential determinant of customer loyalty.

Research limitations/implications: The sample of this study was obtained from a single local chain restaurant in Malaysia.

Practical implications: The findings of this study highlighted the importance for service firms, generally those in the restaurant industry to strengthen the relationship with their customers in pursuit of better competitive advantage and long-term profit.

Originality/value: This study contributes to theoretical knowledge by providing an empirical study on the effect of emotions construct towards the formation of relationship quality within the hospitality industry context.

Keywords: Relationship quality, Patron Dining Experience (PDE), Emotions, Loyalty

Jel Codes: L83, M31

\section{Introduction}

In order to capture customer satisfaction, the old approach of product-oriented marketing has been phased out by the customer-oriented relationship marketing over the years (Grönroos, 1994). Researchers found that meeting customer satisfaction alone is no longer enough to ignite loyalty in them (Rahman \& Kamarulzaman, 2015; Roberts, Varki \& Brodie, 2003; Shammout, 2007). They have suggested that there should be a bond between a firm and its customers and it needs to be maintained. They referred this bond as the relationship quality. 
The research in this relationship quality remains vague and the present study attempts to address this by covering three issues. The first issue is related to the nature of relationships. This is due to the lack of robustness which results from the fast-changing and competitive environment in the chain restaurant industry. The competitive environment has made the development of relationship and sustainability of loyalty becoming increasingly difficult. Nevertheless, determining the underlying determinants is even harder (Aali, Ibrahimi, Mirabi \& Zare, 2014). Hence, this study then suggests the possible new determinants of relationship quality in the chain restaurant industry.

Secondly, this study highlights that the predictors of relationship quality are changing over time. Moreover, the predictors are not generic across fields. However, according to Wang, Liang and Wu (2006), these antecedents of relationship quality have all along been based on relational bonds which consist of financial, social and structural bonds. Hence, this study proposes on forming a generic construct of patron dining experience (PDE) as the predictor of relationship quality in the chain restaurant industry which is consistent with the relational bonds theory.

Thirdly, in order to cover a gap in the relationship quality research, the present study discusses the impact of customer emotions on relationship quality as it lacks systematic investigation. According to Barnes (1997), he maintained that emotional content is the root of every relationship formed. It has been suggested in previous research that empirical evidence of such relationship is needed where the key variables can be the antecedents and consequences of customer emotions (Chen \& Ayoko, 2012; Shammout, 2007; Svari \& Olsen, 2012). The customers' judgment on whether and how they wish to maintain the relationship might be affected by their emotions. Even though attempts have been made by many researchers to explain on how relationship quality is developed, the importance of emotions in this process has received less attention by them (Anderson \& Kumar, 2006; Chen \& Ayoko, 2012; Petzer, De Meyer, Svari \& Svensson, 2012). To address this issue, this study presents the suggested roles of emotions as the new predictor of relationship quality in the chain restaurant industry.

\section{Literature review}

\subsection{Relationship quality}

Smith (1998) in his initial research on relationship quality has found that relationship quality can be described as the measurement of a relationship's strength. As such, relationship quality measures the extent of the parties' needs and expectations are met based on previous events or encounters. Wong and Sohal (2002) refer relationship quality as the proportion of customers' needs, goals, perceptions and desires met in the relationship. A strong relationship quality indicates how well customers are satisfied with the past performance of the service provider, their trust in the service provider's future performance, and their wish to maintain the relationship with the company (Brun, Rajaokelira \& Licard, 2014; Rahman \& Kamarulzaman, 2015; Roberts et al., 2003).

In general, Woo and Ennew (2004) maintain that the relationship quality construct is conceptualized as a multidimensional construct. While the relationship quality construct comprises of different dimensions or components, most researchers in general, agree that the key components of relationship quality are customer satisfaction, trust and commitment to the relationship with the service provider (Aali et al., 2014; Palmatier, Dant, Greval \& Evans, 2006; Shammout, 2007). Palmatier et al. (2006) further strengthen the agreement when they have identified that the most studied dimensions of relationship quality are satisfaction, trust and commitment. Therefore, based on the mentioned studies, this research's structure of relationship quality will be based on the three dimensions; satisfaction, trust and commitment.

Satisfaction has been defined by Liljander and Strandvik (1997) as the affective and cognitive customer's evaluation based on their personal experience throughout the service exchange within the relationship. Consistent with what is proposed by this research, the relationship quality between the patrons and the chain restaurant will be measured by evaluating their satisfaction towards the restaurants.

Trust is generally separated into two dimensions. The first dimension of trust which is credibility is directed on the extent of a firm's word that the customers believe can be relied on and sincere, and of the firm's ability to 
perform its role effectively. This is followed by benevolence as the second dimension of trust which is directed on customers' perception, the extent of how well their welfare is taken care of by the firm. Naoui and Zaiem (2010) have specifically investigated creditability and benevolence trust as different dimensions in the construct on relationship quality. They have found that both dimensions are positively influenced by the antecedents of relationship quality. Consistent with the literature reviews, both dimensions are viewed as the overall construct of trust.

Moorman, Zaltman and Deshpanede (1992) have defined commitment as an enduring desire to maintain a valued relationship and it has been found dominating the discussion on commitment in the literatures of relationship marketing. As a result, most subsequent studies have adopted their definition particularly those studies on commitment as a dimension of relationship quality. In line with this, their definition of commitment has been found sufficient for the present study.

\subsection{Patron Dining Experience (PDE) through relational bonds}

Food service marketing is often subsumed into that of generalized "hospitality" (Wearne \& Morrison, 1996) and in some texts is associated with "tourism" (Kotler \& Bowen, 1996). Both of these groupings tend to favor the restaurant industry. The food service industry has features which set it apart from other areas of the service sector such as financial and professional services (Johns, 1999). It is also closely concerned with the choice of food and quality. As a result, the restaurant patrons' behavior is influenced by complex attributes (Hyun, 2010; Namin, 2017). They have maintained that the patrons' evaluation on these attributes influences their behavior. Consistent with the present study, their view is appropriate to define patron dining experience (PDE) construct in the study. PDE is defined as the response of the patrons to an action, person, environment and stimulus. Different researchers have proposed various attributes to explain patrons' behavior. However, only five of these are widely accepted. They are the quality of the food, the price, the service, the location, and clean environment (Hyun, 2010; Soriano, 2002). These attributes are selected as the foundation to explain the PDE construct. The formation construct is supported by the relational bonding process (financial bonds, social bonds and structural bonds). The relationship marketing researchers have focused on studying only three types of bonds which are financial, social and structural bonds. In later research, the authors have suggested that only by applying all those three types of relational bonds: financial, social, and structural, firms can build relationships with their customers (Shammout, 2007; Wang et al., 2006). Their suggestion is consistent with the present study, where these three relational bonds support the formation of the attributes in patron dining experience (PDE).

Financial bonds are commonly related with retention marketing or better known as frequency marketing. In restaurant marketing context, price has always been considered as an important criterion (Hyun, 2010; Namin, 2017; Soriano, 2002). Marketers must continually improve the quality of products and lower the prices in order to attract and maintain customers. Nevertheless, customers tend to expect higher quality food when the price is high (Hyun, 2010). A reasonable price level is considered as a critical factor influencing customer trust and satisfaction (Andaleeb \& Caskey, 2007) and this is consistent with the construct of relationship quality of the present research. Similar to food quality, it has been defined as a concept that can provide insights on how to rejuvenate products and the way they are viewed by customers (Murphy, Pritchard \& Smith, 2000). Patrons' behavior is seen to be greatly influenced by the quality of food by many researchers in the restaurant industry as well (Auty, 1992; Hyun, 2010; Kivela, Inbakaran \& Reece, 1999). Furthermore, researchers have postulated that customer satisfaction is influenced by all these attributes (Hyun, 2010; Kivela et al., 1999). Moreover, trustworthiness of a restaurant is influenced by food quality as it is related to safety issues, which is consistent with the construct of relationship quality of the present study (Knight, Worosz \& Todd, 2007).

Based on the literature, social bonds are also considered as an important component in the present study to investigate the relationship between buyer and seller in the dining context. Service quality here is viewed as the personal linkages or ties that are established during interaction between restaurant operators and their patrons. Service quality is hypothesized to be a critical factor influencing patrons' behavior in the restaurant industry in a large number of studies (Chow, Lau, Lo, Sha \& Yun, 2007; Soriano, 2002). Moreover, the key determinant of customer satisfaction is strongly believed by previous researchers to be service quality (Chow et al., 2007; 
Ladhari, Brun \& Morales, 2008; Namin, 2017; Soriano, 2002). Gounaris and Venetis (2002) have also suggested that service quality is also a key determinant of trust, which is consistent with the construct of relationship quality of this research.

Smith (1998) has defined structural bonds as the ties linking the structure, governance, and institutionalization of relationship pattern. Structural bonds generally occur when customer problems are being solved in the form of service-delivery systems by businesses in enhancing customer relationships. In this study, the structural bonds are employed to explain the location and environment attributes of the patron dining behavior (PDE) construct. Soriano (2002) has found that restaurant patrons expect a convenient location when they dine out. Lastly, the last attribute of patron dining experience (PDE) which is environment, it greatly influences patrons' behavior as it is a form of communication between a service provider with its customers (Bitner, 1992). This was found by Kivela, Inbakaran and Reece (2000); patrons are likely to return if they are satisfied with the restaurant's ambience.

\subsection{Emotions}

The construct of emotions is often confused with other constructs related to it such as mood, affect and attitude. The different constructs need to be distinguished first. The construct of affect is seen as the broad construct in describing the common state of feelings (Ali, Amin \& Cobanoglu, 2016; Burns \& Neisner, 2006; Krampf, Ueltschy \& Amico, 2003). Some researchers establish a fine distinction between emotions and moods (Krampf et al., 2003). Such researchers associate emotions with action tendencies and describe emotions as a stronger turn-on than moods. In order to further distinguish the construct, Clore, Wyer, Dienes, Gasper, Gohm and Isbell (2001) and Frijda (1993) have regarded moods as generally non-intentional while emotions as typically intentional. The distinction between emotions and attitudes is also suggested by other researchers since emotions represent a more diverse and richer field of phenomenological experience. Krampf et al. (2003) further propose that emotions experience cannot be stored for a long time and then retrieved, as compared to attitudes. Burns and Neisner (2006) and Krampf et al. (2003) have defined emotions by referring to James (1890) whose work is considered as the basis of studying emotions in the early 19th century. During that time, emotions were considered as being complex, involving different patterns of stimulation. Schachter and Singer (1962) similarly viewed emotions through a cognitive appraisal process, as the general state of arousal. Bagozzi, Gopinath and Nyer (1999) however provided a broader definition where they described emotions as being "a mental state of readiness that arises from cognitive appraisals of an events or thoughts; has a phenomenological tone; is accompanied by physiological processes; was often expressed physically; and may result in specific actions to affirm or cope with the emotion, depending on its nature and the person having it."

\subsection{Loyalty}

The core objective of relationship marketing has always been to achieve customer loyalty by establishing and maintaining long-term relationships. Thus, customer loyalty is treated as the concluding dependent variable in the present study. This is supported by several researchers who have maintained that the formation of loyalty is related to relationships (Rahman \& Kamarulzaman, 2015; Sheth \& Parvatiyar, 1995). Consequently, loyalty is identified as the most important part as well as the central to the paradigm of relationship marketing (Hart, Smith, Spark \& Tzokas, 1999; Palmer, 1994). The importance of loyalty can be seen from the idea that it is more profitable to maintain a customer than to find a new one. Its importance is based on the three common concepts of which loyal customers spend more with the company, they are less price-sensitive and they are cheaper to maintain (Berry \& Parasuraman, 1991; Noon, Kimes \& Renaghan, 2003; Tepeci, 1999).

\section{Research model}

The research model of the present study has been developed based on the earlier literature review as illustrated in Figure 3.1. The framework has five main hypotheses which are to be tested. Hypotheses H1 and H2 are proposed to reflect the influence of patrons dining experience (PDE) on relationship quality and customer 
emotions respectively. The effect of emotions on relationship quality is proposed by Hypothesis H3. Meanwhile, the linkage between relationship quality and loyalty is proposed by Hypothesis H4.

\section{Proposed Conceptual Model}

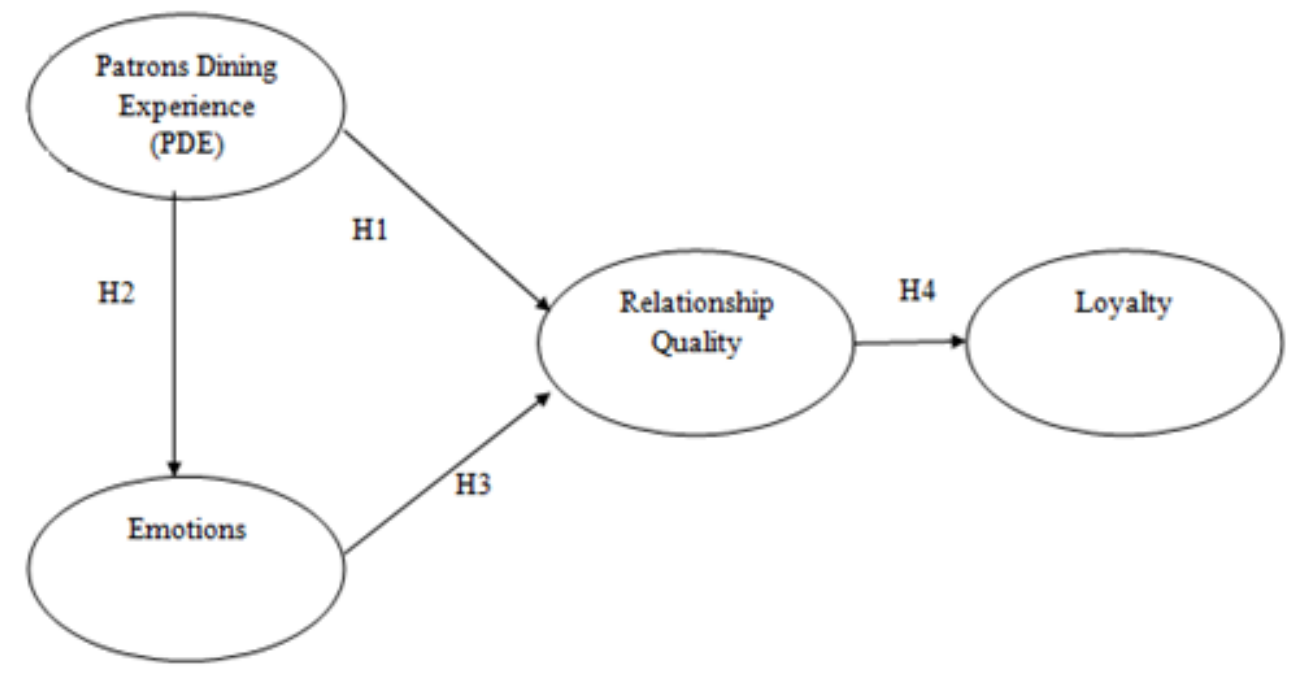

Figure 1. Research Model

\subsection{Patron Dining Experience (PDE) and relationship quality}

The key theoretical linkage in this study is that relationship quality is affected by patron dining experience (PDE), which in turn affects loyalty. As discussed in the literature review, these attributes contributing to PDE are explained through relational bonds. Smith (1998) explained that a series of successive interactions is able to develop either successful relational bonding and vice versa. Smith's (1998) work provided support that relational bonds and relationship quality are linked and advocated the importance of the linkage. He stated that such bonds are able to provide satisfaction to the overall relationship as bonds provide a foundation for the trust needed to risk greater commitment while reducing the risk inherent in voluntary exchange relations with a service provider. Based on above theory and supporting details, the following hypothesis is proposed:

\section{H1: PDE positively influences relationship quality (RQ).}

\subsection{Patron Dining Experience (PDE) and emotion}

The present study also presents the discussion on whether patron dining experience (PDE) affects customer emotions. In particular, the impact of patron dining experience (PDE) on customer emotions has not been empirically examined. To discuss the link between patron dining experience (PDE) and emotions, which was first pointed out by Walls (2003), and it stated on the possibility that emotional link between consumer and provider existed through bonding process. The existence may be at a very deep personal or a brief level. Walls (2003) has maintained that bonds are able to reduce customers' sadness, anxiety and separation distress by providing added feelings of comfort, familiarity and security within the marketplace. Thus, the following hypothesis is proposed:

H2: PDE positively influences emotions (EM). 


\subsection{Emotions and relationship quality}

The theoretical and empirical grounds for the link between emotions and relationship quality have been established (Shammout, 2007; Wong, 2004). It has been found that some researchers have linked emotions with relationship quality as an overall construct consisting of satisfaction, trust and commitment. There have also been some investigation works which linked positive and negative emotions to the relationship quality construct, separately. Wong (2004) provided an explanation for the relationship suggesting that customers elicit various types of emotions during the consumption experience. The service encounter experience overall relationship quality is assessed by customer with emotions conveying important information in the assessing process. Therefore, it can be said that customers are expected to develop positive perceptions towards the overall relationship quality if he/she displays positive emotions during the service encounter. In response, the below hypothesis is proposed:

\section{H3: Customer emotions bave positive influence on relationship quality (RQ).}

\subsection{Relationship quality and loyalty}

Strong evidence has been found in support of the linkage between relationship quality as an overall construct comprising of satisfaction, trust and commitment with loyalty. Shammout (2007) in investigating the link between relationship quality as an overall construct with loyalty, found that satisfaction and trust are strong determinants of loyalty. The result is consistent within the hospitality context, where an increasing amount of evidence in support of the link between relationship quality and loyalty is found. Therefore, based on the support found in the literature, the following hypothesis is proposed:

H4: Relationship quality has positive influence on customer loyalty (LO).

\section{Research methodology, analysis and result}

\subsection{Construct Measurement}

A set of research questionnaires has been developed. The choice of scale items corresponds to a business-tocustomer market context and it is adopted from the most relevant literatures of consumers' perceptions as end users in buyer-seller relationship. The following items were used as shown in Table 1 to Table 4.

Pilot study was conducted on respondents consisting of five marketing experts and fifteen 'Kopitiam' customers. Analysis from Statistical Package for Social Science (SPSS) showed that the alpha coefficients for construct patron dining experience, emotions, relationship quality, brand image and loyalty are all above 0.7 . According to Nunnally (1997), data is generally considered as reliable and acceptable when Cronbach's alpha value shows 0.7 and higher. Thus, the items used in this study can be accepted for further analysis.

The questionnaires were printed in English language and distributed to the patrons in 16 'Kopitiam' outlets throughout Malaysia from April to December 2015 in which a total of 316 sets were collected on the spot. All the respondents are Malaysians 'Kopitiam' patrons. Out of the total respondents, more than half (71.8 percent) of them are male. Looking at the age groups, very few senior citizens of more than 55 years old responded participated in the survey ( 0.6 percent). Most of the respondents are between the age of 26 to 35 years of age (36.1 percent). 


\begin{tabular}{|l|l|l|}
\hline Attributes & Items & Remark \\
\hline Price(PR) & $\begin{array}{l}\text { The price is affordable (PR1) } \\
\text { The price is not expensive (PR2) } \\
\text { The price is more preferable than other restaurants (PR3) } \\
\text { The food and services are value for money (PR4) }\end{array}$ & From Hyun (2010) \\
\hline Food Quality (FQ) & $\begin{array}{l}\text { Serves tasty food (FQ1) } \\
\text { Food is served at the appropriate temperature (FQ2) } \\
\text { Food presentation is attractive (FQ3) } \\
\text { Food is served at the right portion (FQ4) }\end{array}$ & \\
\hline Service Quality (SQ) & $\begin{array}{l}\text { Employees are always willing to help me (SQ1) } \\
\text { The meal is served at the promised time (SQ2) } \\
\text { Employees have the knowledge to answer (SQ3) } \\
\text { Employees are accurate with the orders (SQ4) }\end{array}$ & \\
& $\begin{array}{l}\text { The restaurant is easy to find (LC1) } \\
\text { The restaurant have branches in most places (LC2) } \\
\text { The restaurant is nearly located (LC3) } \\
\text { The restaurants is located in favorable location (LC4) }\end{array}$ & \\
\hline Environment (EN) & $\begin{array}{l}\text { The environment is clean (EN1) } \\
\text { Have nice decorations (EN2) } \\
\text { Provides comfortable environment (EN3) } \\
\text { Have sufficient amenities (EN4) }\end{array}$ & \\
\hline
\end{tabular}

Table 1. Items to Measure Patrons Dining Experience (PDE)

\begin{tabular}{|l|l|l|}
\hline Construct & Items & Remark \\
\hline Satisfaction (SA) & $\begin{array}{l}\text { I am delighted with their performance (SA1) } \\
\text { I am content with their performance (SA2) } \\
\text { I am happy with their performance (SA3) } \\
\text { I am pleased with their performance (SA4) }\end{array}$ & From Hyun (2010) \\
\hline Trust (TR) & $\begin{array}{l}\text { Employees are sincere (TR1) } \\
\text { Employees are honest (TR2) } \\
\text { Employees are reliable (TR3) } \\
\text { Employees are truthful (TR4) }\end{array}$ & From Hyun (2010) \\
\hline Commitment (CO) & $\begin{array}{l}\text { I plan to maintain a long-term relationship (CO1) } \\
\text { I like being associated with them (CO2) } \\
\text { I am committed to my relationship with this restaurant chain (CO3) } \\
\text { I am giving priority to this restaurant chain (CO4 }\end{array}$ & \\
\hline
\end{tabular}

Table 2. Items to Measure Relationship Quality

\begin{tabular}{|l|l|l|l|}
\hline Emotions (EM) & Items (Specific Words) & & Remark \\
\hline Positive & Love (EM1) & Relaxed (EM6) & From Park, Jaworski and \\
& Pleased (EM2) & Mappiness (EM7) & \\
& Welcome (EM3) & Gratitude (EM8) & \\
& Satisfied (EM4) & Pride (EM9) & \\
& Comfortable (EM5) & Delighted (EM10) & \\
\hline Negative & Angry (EM11) & Disappointed (EM16) & \\
& Uneasiness (EM12) & Let down (EM17) & \\
& Ignored (EM13) & Guilt (EM18) & Embarrassment (EM19) \\
& Sadness (EM14) & Frustrated (EM20) & \\
& Fear (EM15) &
\end{tabular}

Table 3. Items to measure Emotion

\begin{tabular}{|l|l|l|}
\hline Dimension & Items & Remark \\
\hline Loyalty (LO) & Say positive things about the chain restaurant to other people (LO1) & From Hyun (2010) and \\
& Encourage friends and relatives to dine at the chain restaurant (LO2) & Shammout (2007) \\
& $\begin{array}{l}\text { Recommend the chain restaurant to someone who seek your advice } \\
\text { (LO3) } \\
\text { Visit the chain restaurant more often (LO4) }\end{array}$ & \\
\hline
\end{tabular}

Table 4. Items to measure loyalty 


\subsection{Measurement model}

The Partial Least Squares (PLS) approach was used to test the proposed research model. This paper adopts the PLS path modeling for its structural model analysis because this study is with the objective to examine the predictors that will influence relationship quality and eventually lead to customer loyalty. The use of PLS is suitable for predictive applications to theory development and finally theory confirmation as PLS helps to reduce a model's complexity with its multidimensional constructs estimation.

The reliability and validity of the measurement models were first determined prior to the structural model analysis. The correlations of each constructs with their respective latent variables (LV) were examined.

All the 60 items for the present study were found to have a loading of $>0.5$ where each construct's AVE $>0.5$ and composite reliability $>0.7$ as shown in Table 5. In PLS, convergent validity can be assessed in terms of factor loadings and average variance extracted (AVE). Items with loadings over the recommended cutoff point of 0.5 with reliability criteria of AVE $>0.5$ and composite reliability $>0.7$ can be accepted for further analysis (Nunnally, 1994).

\begin{tabular}{|l|r|r|}
\hline Construct & AVE & Composite Reliability \\
\hline PR & 0.636 & 0.874 \\
\hline FQ & 0.829 & 0.936 \\
\hline SQ & 0.636 & 0.875 \\
\hline LC & 0.863 & 0.950 \\
\hline EN & 0.607 & 0.859 \\
\hline EM & 0.560 & 0.835 \\
\hline RQ & 0.585 & 0.849 \\
\hline LO & 0.625 & 0.869 \\
\hline
\end{tabular}

Table 5. Composite Reliability

The square root of all average variance extracted values (AVE) for each construct were compared to examine the discriminant validity. The value of the construct itself should exceed all the inter-factor correlations between each other constructs. The results of the discriminant validity for the constructs of this study are presented in Table 6. The results show that all square roots of AVE values are greater than the corresponding correlation estimates, the scales developed for different constructs are indeed measuring the correct intended construct.

\begin{tabular}{|c|c|c|c|c|c|c|c|c|c|c|}
\hline & $\mathrm{CO}$ & EM & EN & FQ & LC & LO & PR & SA & SQ & TR \\
\hline $\mathrm{CO}$ & 0.817 & & & & & & & & & \\
\hline EM & -0.168 & 0.776 & & & & & & & & \\
\hline EN & -0.074 & 0.130 & 0.779 & & & & & & & \\
\hline FQ & 0.256 & -0.250 & 0.115 & 0.910 & & & & & & \\
\hline LC & 0.288 & -0.277 & 0.228 & 0.562 & 0.929 & & & & & \\
\hline LO & 0.116 & 0.118 & 0.049 & -0.041 & -0.035 & 0.765 & & & & \\
\hline PR & -0.015 & 0.092 & 0.302 & 0.206 & 0.274 & 0.119 & 0.797 & & & \\
\hline SA & 0.242 & -0.242 & 0.272 & 0.321 & 0.413 & 0.087 & 0.217 & 0.889 & & \\
\hline SQ & 0.226 & -0.160 & 0.215 & 0.746 & 0.769 & -0.091 & 0.324 & 0.342 & 0.797 & \\
\hline TR & 0.441 & -0.264 & 0.220 & 0.394 & 0.441 & 0.024 & 0.207 & 0.822 & 0.418 & 0.755 \\
\hline
\end{tabular}

Table 6. Discriminant Validity

\subsection{Structural model}

Once the validity and reliability of the measurement model had been checked, an empirical structural model was developed to test the proposed hypotheses. The hypotheses were tested by examining the path coefficients $(\beta)$ and their levels of significance where the path coefficient values are standardized on range from -1 to +1 . Next, bootstrapping was carried out with 500 subsamples to generate the standard errors and $\mathrm{t}$-values, which permits the $\beta$ values (path coefficients) to be made statistically significant. 
The results are shown in Table 7. Based on the $t$-values, all paths are found significant as the $t$-value $\geq 1.96$ at 0.05 level of significance. The predictors of $\operatorname{PDE}(\beta=.211, \mathrm{p}<0.05)$ and $\operatorname{EM}(\beta=.428, \mathrm{p}<0.05)$ are positively related on RQ. Furthermore, the predictors of $\operatorname{PDE}(\beta=.365, \mathrm{p}<0.05)$ is positively related on EM and RQ $(\beta=$. $638, \mathrm{p}<0.05)$ is also found positively related on LO. Hence, the results show that all hypotheses are supported. The explained variance for the endogenous variables in this model are substantial. The direct influence of PDE and EM accounted for approximately 63.8 percent of the variance $(\mathrm{R} 2=.638)$ in $\mathrm{RQ}$, while RQ accounted for approximately 56.3 percent of the variance $(\mathrm{R} 2=.563)$ in $\mathrm{LO}$.

\begin{tabular}{|c|c|c|c|c|}
\hline Hypothesis & & B Value & $\mathrm{t}$-value & Decision \\
\hline $\mathrm{H} 1$ & PDE -> RQ & 0.211 & 2.938 & Supported \\
\hline $\mathrm{H} 2$ & PDE -> EM & 0.365 & 3.909 & Supported \\
\hline H3 & EM -> RQ & 0.428 & 4.825 & Supported \\
\hline $\mathrm{H} 4$ & RQ -> LO & 0.638 & 5.109 & Supported \\
\hline
\end{tabular}

Table 7. Results of Structural Model

Collectively, the results both support and build on the extant literature. As to the former, the findings indicate that both patron dining experience (PDE) and emotion lead to relationship quality. Findings of this research provide additional support for a number of previous studies, such as Hyun (2010), who demonstrated that patron dining experience (PDE) has a significant impact on relationship quality. More importantly, these findings add weight to Chen and Ayoko (2012) suggestions that customer emotions can lead to building relationship between the customers and service providers. The results also provide empirical support for PDE and emotion relationship which has not been empirically examined. As was hypothesized, the results demonstrate a positive relationship between the constructs. From a managerial standpoint, this stresses the importance of PDE and emotion as important predictors in building relationship and loyalty.

\section{Conclusion}

After reviewing the literature, it is found that the development of the relationship quality's conceptual foundations has not been fully investigated up to date. According to Eiriz and Wilson (2006), the key elements that best capture relationship quality vary and there is no agreement between researchers on which to be used in different industries. However, it can be agreed upon that the antecedents should be based on relational bonds. To the best of the researcher's knowledge, limited studies were found to have explained on the formation of antecedents of relationship quality in the dining industry. This paper attempts to explain the formation of these antecedents from the relational bonding theory and process. It is hoped that this study contributes to the body of knowledge on relationship quality by proposing a set of predictor, patron dining experience (PDE) which its formation is based on relational bonds.

Furthermore, although attempts have been made by many researchers to explain on how relationship marketing is developed, the importance of emotions in this process has received less attention by them (Petzer et al., 2012). The inclusion of emotions in the study context provides additional contributions. This paper fills the gap in providing a study on the impact of customer emotions on relationship quality, reported before as limited and lacking (Chen \& Ayoko, 2012; Petzer et al., 2012; Svari \& Olsen, 2012). In addition, the thesis also investigated the impact of patron dining experience (PDE) on customer emotions as well. It is hoped that the additional empirical evidence from this study will contribute to the body of knowledge on customer emotions in relationship marketing aimed at building relationship quality between customers with their service providers.

In addition, there is limited research on relationship quality done till date in country Malaysia. This is with the exception of a study by Rahman and Kamarulzaman (2015) in the hotel industry and Ndubisi, Khoo-Lattimore, Yang and Capel (2011) in the banking industry. There is hardly any study that has taken the initiative to investigate relationship quality and its determinants in chain restaurant industry in Malaysia, to the best of the author's knowledge. It is important to initiate a research in Malaysia as its situation may be different from other countries due to its various and different cultures. 
The study has found significance relationship between patron dining experience (PDE) and emotions with relationship quality which finally lead to loyalty, as well as the evidence of the relationships between PDE and emotions.

\section{Implication}

Looking at a managerial perspective, the importance of managers of services to develop and maintain relationship activities that achieve customer loyalty was highlighted in this thesis, particularly at chain restaurant industry. Specifically, managers should be aware that employing strategies to improve both patron dining experience and customer emotions are necessary to enhance the quality of relationship that customers have with them. As suggested by our model, customer loyalty will develop if the formation of patron dining experience, emotions and relationship quality are well managed. This is of utmost importance because the results of this paper confirm that customers are likely to be loyal when they feel they have high quality relationships with the chain restaurant. Therefore, strategies that will improve the relationship quality with customers should be implemented by service providers for the sake of customer retention.

\section{Limitation}

The data were gathered from a single particular chain restaurant throughout Malaysia to ensure homogeneity as the patrons of 'Kopitiam' best represent the multi-cultural society of Malaysia. However, this paper only covered the outlets in Peninsular Malaysia. According to Lam et al. (2004), an increased sample size of the study will help in the hypothesis testing as they are closely related. Future researches can look into increasing number of respondents in their study, data from East Malaysia should be gathered and utilised as well.

\section{Declaration of Conflicting Interests}

The authors declared no potential conflicts of interest with respect to the research, authorship, and/or publication of this article.

\section{Funding}

This paper is financially supported by Research University Grants awarded by Universiti Teknologi Malaysia (Grant No: Q.J13000.2529.18H26).

\section{References}

Aali, S., Ibrahimi, A., Mirabi, V.R., \& Zare, S. (2014). Effects of Relationship Marketing Strategies on Customer Responses in Iran's Banking Industry: Role of Mediator the Relationship Quality. Research Journal of Recent Sciences, 3(5), 43-54.

Ali, F., Amin, M., \& Cobanoglu, C. (2016). An integrated model of service experience, emotions, satisfaction, and price acceptance: An empirical analysis in the Chinese hospitality industry. Journal of Hospitality Marketing \& Management, 25(4), 449-475. https://doi.org/10.1080/19368623.2015.1019172

Andaleeb, S.S., Caskey, A. (2007). Satisfaction with food services: Insights from a college cafeteria. Journal of Foodservice Business Research, 10(2), 51-65. https://doi.org/10.1300/J369v10n02_04

Anderson, P.H., \& Kumar, R. (2006). Emotions, trust and relationship development in business relationships: A conceptual model for buyer-seller dyads. Industrial Marketing Management, 35(4), 522-535.

https://doi.org/10.1016/j.indmarman.2004.10.010

Auty, S. (1992). Consumer choice and segmentation in the restaurant industry. Service Industries Journal, 12(3), 324-339. https://doi.org/10.1080/02642069200000042

Bagozzi, R.P., Gopinath, M., \& Nyer, P.U. (1999). The role of emotions in marketing. Journal of the Academy of Marketing Science, 27(2), 184-206. https://doi.org/10.1177/0092070399272005 
Barnes, J.G. (1997). Closeness, strength, and satisfaction: Examining the nature of relationships between providers of financial services and their retail customers. Psychology and Marketing, 14(8), 765-790. https://doi.org/10.1002/(SICI)1520-6793(199712)14:8<765::AID-MAR3>3.0.CO;2-C

Berry, L.L., \& Parasuraman, A. (1991). Marketing Services: Competing Through Quality. New York:: The Free Press.

Bitner, M.J. (1992). Servicescapes: The impact of physical surroundings on customers and employees. Journal of Marketing, 56(2), 57-71. https://doi.org/10.2307/1252042

Brun, I., Rajaobelina, A., \& Ricard, L. (2014). Online relationship quality: Scale development and initial testing. International Journal of Bank Marketing, 32(1), 5-27. https://doi.org/10.1108/IJBM-02-2013-0022

Burns, D.J., \& Neisner, L. (2006). Customer satisfaction in a retail setting: The contribution of emotion. International Journal of Retail \& Distribution Management, 34(1), 49-66. https://doi.org/10.1108/09590550610642819

Chen, M.J. \& Ayoko, O.B. (2012). Conflict and trust: the mediating effects of emotional arousal and selfconscious emotions. International Journal of Conflict Management, 23(1), 19-56.

https://doi.org/10.1108/10444061211199313

Chow, I.H., Lau, V.P., Lo, T.W., Sha, Z., \& Yun, H. (2007). Service quality in restaurant operations in China: Decision- and experiential-oriented perspectives. International Journal of Hospitality Management, 26(3), 698-710. https://doi.org/10.1016/j.ijhm.2006.07.001

Clore, G.L., Wyer, R.S., Dienes, B., Gasper, K., Gohm, C., \& Isbell, L. (2001). Affective feelings as feedback: Some cognitive consequences. In L. L. a. C. In Martin, G. L. (Ed.), Theories of Mood and Cognition: a user's Handbook. Mahwah, NJ: Lawrance Erlbaum Associates.

Eiriz, V., \& Wilson, D. (2006). Research in relationship marketing: Antecedents, traditions and integration. European Journal of Marketing, 4(3/4), 275-291. https://doi.org/10.1108/03090560610648057

Frijda, N. (1993). Mood, emotion episodes and emotions. In M. Lewis \& J. M. Haviland (Eds.), Handbook of Emotions (pp. 381-403). New York, N.Y: Guilford.

Gounaris, S.P., \& Venetis, K. (2002). Trust in industrial service relationships: Behavioral consequences, antecedents and the moderating effect of the duration of the relationship. Journal of Services Marketing, 16(7), 636-655. https://doi.org/10.1108/08876040210447351

Grönroos, C. (1994). From marketing mix to relationship marketing: Towards a paradigm shift in marketing. Management Decision, 32(2), 4-20. https://doi.org/10.1108/00251749410054774

Hart, S., Smith, A., Spark, L., \& Tzokas, N. (1999). Are loyalty schemes a manifestation of relationship marketing?. Journal of Marketing Management, 15(6), 541-562. https://doi.org/10.1362/026725799785045842

Hyun, S. (2010), Predictors of relationship quality and loyalty in the chain restaurant industry. Cornell Hospitality Quarterly, 51(2), 251-267. https://doi.org/10.1177/1938965510363264

James, W. (1890). Principles of Psychology. New York: Holt.

Johns, N. (1999). The meal experience: A matter of signs?. Hospitality Review, 1(4), 50-54.

Kivela, J., Inbakaran, R., \& Reece, J. (1999). Consumer research in the restaurant environment, part 1: A conceptual model of dining satisfaction and return patronage. International Journal of Contemporary Hospitality Management, 11(5), 205-222. https://doi.org/10.1108/09596119910272739

Kivela, J., Inbakaran, R., \& Reece, J. (2000). Consumer research in the restaurant environment, part 3: Analysis, finding and conclusions. International Journal of Contemporary Hospitality Management, 12(1), 13-30.

https://doi.org/10.1108/09596110010304984

Knight, A.J., Worosz, M.R., \& Todd, E.C.D. (2007). Serving food safety: Consumer perceptions of food safety at restaurants. International Journal of Contemporary Hospitality Management, 19(6), 476-484.

https://doi.org/10.1108/09596110710775138 
Kotler, P., \& Bowen, J.T. (1996). Marketing for Hospitality and Tourism. Upper Saddle River, NJ.: Prentice-Hall.

Krampf, R., Ueltschy, L., \& Amico, M. (2003). The contribution of emotion to consumer satisfaction in the service setting. The Marketing Management Journal, 13(1), 32-52.

Ladhari, R., Brun, I., \& Morales, M. (2008). Determinants of dining satisfaction and post-dining behavior intentions. International Journal of Hospitality Management, 27(4), 563-573.

https://doi.org/10.1016/j.ijhm.2007.07.025

Liljander, V., \& Strandvik, T. (1997). Emotions in service satisfaction. International Journal of Service Industry Management, 8(2), 148-169. https://doi.org/10.1108/09564239710166272

Moorman, C., Zaltman, G., \& Deshpanede, R. (1992). Relationship between providers and users of market research: The dynamics of trust within and between organizations. Journal of Marketing Research, 29(3), 314-329. https://doi.org/10.2307/3172742

Murphy, P., Pritchard, M.P., \& Smith, B. (2000). The destination product and its impact on traveler perceptions. Tourism Management, 21(1), 43-52. https://doi.org/10.1016/S0261-5177(99)00080-1

Namin, A. (2017). Revisiting customers' perception of service quality in fast food restaurants. Journal of Retailing and Consumer Services, 34, 70-81. https://doi.org/10.1016/j.jretconser.2016.09.008

Naoui F.B. \& Zaiem I. (2010). The impact of relationship quality on client's loyalty: An application in the parapharmaceutical industry. International Journal of Pharmaceutical and Healthcare Marketing, 4(2), 137-156. https://doi.org/10.1108/17506121011059759

Ndubisi, N.O., Khoo-Lattimore, C., Yang, L. \& Capel, C.M. (2011). The antecedents of relationship quality in Malaysia and New Zealand. International Journal of Quality and Reliability Management, 28(2), 233-248. https://doi.org/10.1108/02656711111101773

Noon, B.M., Kimes, S.E., \& Renaghan, L. (2003). Integrating customer relationship management and revenue management: A hotel perspective. Journal of Revenue Management and Pricing Management, 2(1), 7-21. https://doi.org/10.1057/palgrave.rpm.5170045

Nunnally, J.C., \& Bernstein, I.H. (1994). Psychometric theory (3 ed.). New York: McGraw-Hill.

Palmatier, P., Dant, R.P., Grewal, D., \& Evans, K.R. (2006). Factors influencing the effectiveness of relationship marketing: A meta-analysis. Journal of Marketing, 70(October), 136-156. https://doi.org/10.1509/jmkg.70.4.136

Palmer, A. (1994). Relationship marketing: Back to basic?. Journal of Marketing Management, 10(7), 571-578. https://doi.org/10.1080/0267257X.1994.9964305

Park, C.W., Jaworski, B.J., \& Maclnnis, D.J. (1986). Strategic brand concept image management. Journal of Marketing, 50(4), 135-145. https://doi.org/10.2307/1251291

Petzer, D.F., De Meyer, C.F., Svari, S. \& Svensson, G. (2012). Service receivers' negative emotions in airline and hospital service settings. Journal of Services Marketing, 26(7), 484-496.

https://doi.org/10.1108/08876041211266413

Rahman, M.A., \& Kamarulzaman, Y. (2015). The influence of relationship quality in the context of outsourcing relationships in the Malaysian hotel industry. International Journal of Applied Business and Economic Research, 13(5), 3379-3392.

Roberts, K., Varki, S., \& Brodie, R. (2003). Measuring the quality of relationships in consumer services: An empirical study. European Journal of Marketing, 37(1/2), 169-196. https://doi.org/10.1108/03090560310454037

Schachter, S., \& Singer, J.E. (1962). Cognitive, social and psychological determinants of emotional states. Psychological Review, 69(5), 379-399. https://doi.org/10.1037/h0046234

Shammout, A.B. (2007). Evaluating an Extended Relationship Marketing Model for Arab Guests of Five-Star Hotels. A thesis submitted for the degree of Doctor of Philosophy, Victoria University, Melbourne. 
Sheth, J. N., \& Parvatiyar, A. (1995). Relationship marketing in consumer market: Antecedents and consequences. Journal of the Academy of Marketing Science, 23(4), 255-271. https://doi.org/10.1177/009207039502300405

Smith, B. (1998). Buyer-seller relationship: Bonds, relationship management, and sex type. Canadian Journal of Administrative Sciences, 15(1), 76-92. https://doi.org/10.1111/j.1936-4490.1998.tb00153.x

Soriano, D.R. (2002). Customers' expectations factors in restaurants: The situation in Spain. International Journal of Quality and Reliability Management, 19(8/9), 1055-1068. https://doi.org/10.1108/02656710210438122

Svari, S, \& Olsen, L.E. (2012). The role of emotions in customer complaint behaviors. International Journal of Quality and Service Sciences, 4(3), 270-282. https://doi.org/10.1108/17566691211269585

Tepeci, M. (1999). Increasing brand loyalty in the hospitality industry. International Journal of Contemporary Hospitality Management, 11(5), 223-229. https://doi.org/10.1108/09596119910272757

Walls, S. (2003). Relationship marketing: The dyadic bonding experience between a consumer and a company. Unpublished doctoral dissertation, The University of Tennesse, Knoxville.

Wang, W., Liang, C., \& Wu, Y. (2006). Relationship bonding tactics, relationship quality and customer behavioural loyalty-behavioural sequence in Taiwan's information service industry. Journal of Service Research, 6(1), 31-57.

Wearne, N., \& Morrison, A. (1996). Hospitality Marketing. Oxford: Butterworth-Heinemann.

Wong, A. (2004). The role of emotional satisfaction in service encounter. Managing Service Quality, 14(5), 365-376. https://doi.org/10.1108/09604520410557976

Wong, A., \& Sohal, A. (2002). An examination of the relationship between trust, commitment and relationship quality. International Journal of Retail \& Distribution Management, 30(1), 34-50.

https://doi.org/10.1108/09590550210415248

Woo, K., \& Ennew, C.T. (2004). Business-to-business relationship quality: An IMP interaction-based conceptualisation and Measurement. European Journal of Marketing, 38(9/10), 1252-1271.

https://doi.org/10.1108/03090560410548960

Intangible Capital, 2018 (www.intangiblecapital.org)

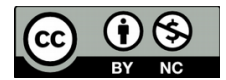

Article's contents are provided on an Attribution-Non Commercial 4.0 Creative commons International License. Readers are allowed to copy, distribute and communicate article's contents, provided the author's and Intangible Capital's names are included. It must not be used for commercial purposes. To see the complete license contents, please visit https://creativecommons.org/licenses/by-nc/4.0/. 